\title{
GENETIC CHARACTERIZATION OF OLD GRAPEVINES COLLECTED IN OASES OF THE ATACAMA DESERT
}

\author{
Ingrid Poblete', Manuel Pinto², María Teresa de Andrés ${ }^{3}$, and Patricio Hinrichsen²*
}

Old grapevine (Vitis vinifera L.) accessions are a source of genes that could be rescued for use per se or in modern breeding programs. The first step in this rescuing is collecting and characterizing the germplasm from a particular region. This study presents the genetic characterization of 21 grapevine accessions collected from the Atacama Desert in the far North of Chile. Characterization was based on 12 microsatellites (Simple Sequence Repeats, or SSRs) supplemented with Amplified Fragment Length Polymorphic (AFLP) markers. Most of the collected accessions produced red berries and shared the genetic characteristics of the cv. País, an old genotype found throughout America. However, among those red-berried accessions, one showed a severe abortive phenotype (22S7), and another (6S4) differed from 'País' in one allele. Both could be examples of somatic mutations, even though no variations in their AFLP patterns were found. On the other hand, the only accession with red berries that exhibited genetic characteristics different from those of 'País' (5CN) corresponded to 'Gros Colman', a supposedly Georgian genotype introduced to this region by the mid- $20^{\text {th }}$ century. Greater genetic diversity was detected among the white and pink accessions, which were classified into five clades based on their SSR allelic patterns. Of these genotypes, 11Si was identified as 'Emperatriz' or 'Red Seedless', an Argentinean variety; accessions 16H1 and $17 \mathrm{H} 2$ corresponded to a product of crossing 'País' and 'Muscat of Alexandria'; and, finally, accession 20S5 was identified as 'Ahmeur bou Ahmeur', an Algerian genotype harboring pink berries. Two seeded genotypes harboring small and large white berries were not identified as known varieties. The possible use of these accessions for breeding to enhance survival in the harsh environment of the Atacama Desert is discussed.

Key words: Vitis vinifera, SSR, AFLP, Atacama Desert, germplasm, 'Listán Prieto’.

$\mathrm{T}$ he European grape, Vitis vinifera L., was introduced to America by the Spanish during the colonial period and was extensively cultivated by Catholic friars who used wine for their religious services. The first vines were planted in what is now the Dominican Republic and from there grape cultivation spread to Mexico and Peru. In Chile, viticulture began in the valleys of Copiapó $\left(26^{\circ} \mathrm{S}\right)$ and Elqui $\left(29^{\circ} \mathrm{S}\right)$ and probably in oases of the Atacama Desert around the middle of the 16th century (Del Pozo, 1998). In the Oasis de Pica (20³0’ S, 69²1' W, Figure 1 ), for example, grape cultivation dates back to the late 16th century (Billinghurst, 1893). Names such as 'Italia', 'Mollar de Granada', 'Castellana', 'Muscat', 'Bordalesa' and 'Tintilla' are mentioned by Billinghurst (1893), but since this report does not provide morphological descriptions of these genotypes, they might correspond to one or a few cultivars, and those names do not necessarily

${ }^{1}$ Universidad Arturo Prat, Departamento Agricultura del Desierto y Biotecnología, Casilla 121, Iquique, Chile.

${ }^{2}$ Instituto de Investigaciones Agropecuarias INIA, Centro de Investigación La Platina, PO Box 439-3, Santiago, Chile. *Corresponding author (phinrichsen@inia.cl).

${ }^{3}$ Instituto Madrileño de Investigación y Desarrollo Rural, Agrario y Alimentario IMIDRA, Laboratorio de Biotecnología, Finca El Encín, Apto. 127, 28,800 Alcalá de Henares, Madrid, España.

Received: 4 January 2010.

Accepted: 3 May 2011 correspond to the modern varieties using the same or a similar denomination; such is the case of 'Italia Pirovano' and a large series of Muscat flavored varieties cultivated

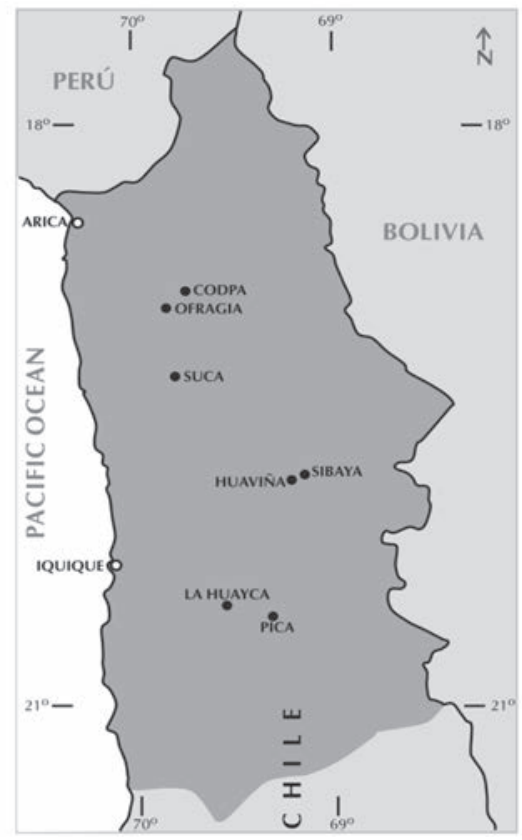

Figure 1. Geographic locations of the sample-collection sites in the Atacama Desert, Chile. 
in many places. We do not know if the extant plants correspond to any of those names. The same author reported that $160000 \mathrm{~L}$ of an alcoholic sweet wine of the Oporto type was produced from 'Tintilla' in the Oasis de Pica, Matilla and Puquios. 'Tintilla' was apparently the predominant cultivar until 1932, when the production and sale of alcoholic beverages were banned by law in mining establishments in Northern Chile. This prohibition ended with the commercial cultivation of grapes in these oases, in some of which the remaining plants are still being grown, generally as a home garden plant. These plants have survived under adverse conditions, with little water and warm winter conditions, in soils with high salinity and boron concentrations and in areas with high radiation levels (500-550 cal $\mathrm{cm}^{-2} \mathrm{~d}^{-1}$ ), including UV-B radiation. Their ability to grow under these extreme conditions makes this germplasm an interesting material for physiological studies and breeding purposes.

Among the original cultivars introduced in America, the most common were 'Negra Peruana' and 'Rosa del Perú', planted in Peru; 'Mission' or 'Misión', grown in California; and 'País', grown in Chile. Milla-Tapia et al. (2007) studied the genetic relationships among these cultivars and concluded that all of them belong to the same genotype, originally known in the Canary Islands as 'Moscatel Negra' and in Morocco as 'Hariri'. In Spain, there are records that date back to the 16th century of a variety named 'Listan Prieto', which, according to Martínez (1998), is identical to 'Moscatel Negra'.

Most of the grapes currently grown in the oases of the Atacama Desert have red berries; therefore, it is possible to hypothesize that at least some of them correspond to the abovementioned group of genotypes. To prove this hypothesis, the most simple and efficient way is to use microsatellite markers, which have been widely used with this same purpose in grapes (Santiago et al., 2005; Martínez et al., 2006; Milla-Tapia et al., 2007; Ibáñez et al., 2009). These markers are highly polymorphic, easily analyzed, and co-dominant, and there is a large pool of data to be consulted for comparisons, including databases built at the Domaine de Vassal in France and at the El Encín in Spain.

The objectives of this study were to characterize the genetic diversity of grapevine accessions collected from different locations in the Northern Chile (Atacama Desert) and to determine their identity.

\section{MATERIALS AND METHODS}

\section{Collection and establishment of vine accessions from the Atacama Desert}

Cuttings were collected in the winter of 2003 from old plants growing in oases and small valleys surrounded by large portions of extremely arid land. A total of 21 accessions were collected. In most cases, no records of the age of the sampled plants were available, but trunk diameter measurements and local growers' information suggest that most of them have been growing at the collection sites for more than a century. There is evidence indicating that at least some of these plants show resistance to high salinity and B concentration in the soil, which is characteristic of the local environment (Ferreyra et al., 1997). Cuttings were collected from the following locations (Figure 1): Codpa (18 ${ }^{\circ} 50^{\prime} \mathrm{S}, 6^{\circ} 45^{\prime} \mathrm{W}$ ), Ofragia $\left(18^{\circ} 50^{\prime} \mathrm{S}, 69^{\circ} 45^{\prime} \mathrm{W}\right)$, Suca $\left(19^{\circ} 41^{\prime} \mathrm{S}, 69^{\circ} 45^{\prime} \mathrm{W}\right)$,

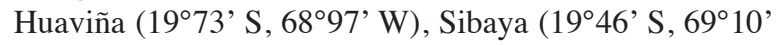

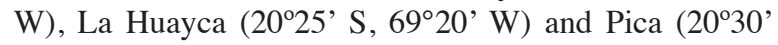
$\left.\mathrm{S}, 69^{\circ} 21^{\prime} \mathrm{W}\right)$. Most of the cuttings were collected from isolated plants, grown with little or no care and without any trellis system (Table 1). Small vineyards existed in Codpa, Ofragia, and Suca, which were used to produce a local wine under agronomic management that was limited to irrigation, pruning and manure incorporation. In La Huayca, cuttings were obtained from a vineyard planted circa 1950. Cuttings were rooted in $1 \mathrm{~L}$ plastic containers filled with a substrate composed of soil and compost (1:1). Once rooted, plants (five to ten per accession) were transferred to the field and planted during the winter of 2004 in hedgerows in positions of $2.0 \mathrm{~m}$ between rows and $1.5 \mathrm{~m}$ over the row at the Canchones Experimental Station $\left(20^{\circ} 25^{\prime} \mathrm{S}, 69^{\circ} 20^{\prime} \mathrm{W}\right)$ of the Universidad Arturo Prat, Iquique. The textural composition of the soil at the site of plantation was $71.8 \%$ sand, $14.4 \%$ silt, and $13.8 \%$ clay and was enriched with organic matter prior to planting. Under these conditions, the soil B concentration averaged $7 \mathrm{mg} \mathrm{L}^{-1}$. Plants were drip irrigated according to standard procedures, with water containing an average of $2 \mathrm{mg} \mathrm{B} \mathrm{L}^{-1}$.

As a reference for the study, cv. País was also planted and plants were produced using the procedure described above, but with cuttings obtained from Estación

Table 1. List of accessions and references and their geographical origin: The skin color of berries is also indicated.

\begin{tabular}{lccc}
\hline $\begin{array}{l}\text { Accession } \\
\text { code }\end{array}$ & $\begin{array}{c}\text { Geographical } \\
\text { origin }\end{array}$ & $\begin{array}{c}\text { Name for } \\
\text { the analysis }\end{array}$ & $\begin{array}{c}\text { Berry skin } \\
\text { color }\end{array}$ \\
\hline $1 \mathrm{C} 1$ & Codpa & Codpa-1 & Red \\
$2 \mathrm{C} 2$ & Codpa & Codpa-2 & Red \\
$3 \mathrm{C} 4$ & Codpa & Codpa-4 & Red \\
$4 \mathrm{C} 5$ & Codpa & Codpa-5 & Red \\
$5 \mathrm{CN}$ & La Huayca & Canchones & Red \\
$6 \mathrm{~S} 4$ & Suca & Suca-4 & Red \\
$8 \mathrm{P} 3$ & Pica & Pica-3 & Red \\
$9 \mathrm{~Pa}$ & Cauquenes, Chile & País & Red \\
$10 \mathrm{C} 3$ & Codpa & Codpa-3 & Red \\
$11 \mathrm{Si}$ & Sibaya & Sibaya & Pink \\
$12 \mathrm{P} 2$ & Pica & Pica-2 & Red \\
$13 \mathrm{P} 4$ & Pica & Pica-4 & White \\
$14 \mathrm{P} 1$ & Pica & Pica-1 & White \\
$16 \mathrm{H} 1$ & Huaviña & Huaviña-1 & White \\
$17 \mathrm{H} 2$ & Huaviña & Huaviña-2 & White \\
$18 \mathrm{~S} 1$ & Suca & Suca-1 & White \\
$19 \mathrm{~S} 2$ & Suca & Suca-2 & White \\
$20 \mathrm{~S} 5$ & Suca & Suca-5 & Pink \\
$21 \mathrm{~S} 6$ & Suca & Suca-6 & White \\
$22 \mathrm{~S} 7$ & Suca & Suca-6A & Red \\
$23 \mathrm{Ha}$ & Hariri, Morocco' & Hariri & Red \\
$25 \mathrm{P} 5$ & Pica & Pica 1B & Red \\
$27 \mathrm{O}$ & Ofragia & Ofragia & Red \\
\hline 'Data of 'Hariri' berries obtained from Milla-Tapia et al. (2007). &
\end{tabular}


Experimental Cauquenes $\left(35^{\circ} 58^{\prime} \mathrm{S}, 72^{\circ} 17^{\prime} \mathrm{W}\right)$ of the Instituto de Investigaciones Agropecuarias INIA, located in central Chile.

\section{Sample preparation and microsatellite analysis}

Young leaf samples were obtained from individual plants, frozen in liquid $\mathrm{N}_{2}$ and kept at $-80{ }^{\circ} \mathrm{C}$ until used. DNA extraction was performed as described by Narváez et al. (2001). DNA quality was ascertained by $1 \%$ agarose gel electrophoresis and its concentration measured by absorbance at $260 \mathrm{~nm}$. For microsatellite analysis, DNA samples derived from 'País' and 'Hariri' were used as references. The second sample, identical to 'País', was obtained from the Domaine de Vassal germplasm bank (INRA-Montpellier, France) (MillaTapia et al., 2007).

\section{Microsatellite analysis}

Twelve microsatellite region (SSR) markers were used in a first round of analyses: VVS2, VMC8g9, VMC9h4-2, VMC5h5, VMC5g7, VVMD5, VVMD25, VVMD7, VVMD27, VVMD28, VrZAG62, and VrZAG79 (Thomas and Scott, 1993; Bowers et al., 1996; 1999; Sefc et al., 1999), most of which have a high discriminatory capacity, evidenced by their polymorphic information content (PIC), which is an index describing the ability of a marker to differentiate individual accessions from a larger set (Narváez et al., 2001; This et al., 2004). The VMC-type microsatellites were developed by the Vitis Microsatellite Consortium (www.agrogene.com). The polymerase chain reactions (PCR) were performed in a Perkin Elmer thermocycler, using the following mixture: $4 \mu \mathrm{L}$ DNA (diluted to $10 \mathrm{ng} \mathrm{uL}^{-1}$ ), $1.6 \mu \mathrm{L} 10 \mathrm{X}$ buffer (Tris-HCl 150 $\mathrm{mM}, \mathrm{KCl} 500 \mathrm{mM}, \mathrm{pH} 8.0), 0.4 \mu \mathrm{L} \mathrm{MgCl}_{2} 50 \mathrm{mM}, 1.6 \mathrm{uL}$ dNTPs (250 uM each), $1 \mu \mathrm{L}$ primer mix (0.5 uM each), $0.4 \mu \mathrm{L}$ Taq polymerase and $7 \mu \mathrm{L} \mathrm{H}_{2} \mathrm{O}$. The amplification program consisted of a denaturation step at $95{ }^{\circ} \mathrm{C}$ for 5 min, followed by 35 cycles at $95^{\circ} \mathrm{C}$ for $45 \mathrm{~s}$, annealing at $56{ }^{\circ} \mathrm{C}$ for $45 \mathrm{~s}$, extension at $72{ }^{\circ} \mathrm{C}$ for $90 \mathrm{~s}$, and a final elongation at $72{ }^{\circ} \mathrm{C}$ for $7 \mathrm{~min}$. Separation and analysis of alleles were performed as previously described (Narváez et al., 2001).

In a second set of experiments, when allelic patterns were different from those of 'País', we compared these accessions to those maintained at one of the world's largest germplasm collections (Finca El Encín, IMIDRA, Spain), containing 1699 unique genotypes including $V$. vinifera cultivars, rootstocks, wild populations, and other species of the genus Vitis (J. Borrego, 2010, IMIDRA; personal communication). Since most of these accessions are of Spanish origin, the possibility of finding identical accessions is greater, as demonstrated recently with 'País' (Milla-Tapia et al., 2007). With this goal in mind, accessions were studied with a set of 20 microsatellite loci in order to establish varietal identities and possible parentage relationships. The genotypes were obtained using two independent multiplex PCRs, labeled as A and B, as described previously (Ibáñez et al., 2009). The multiplex PCR A included 11 microsatellites: VVS2 (Thomas and Scott, 1993), VVMD7, VVMD24, VVMD25 (Bowers et al., 1996; 1999), VVIB01, VVIH54, VVIN73, VVIP31, VVIP60, VVIQ52 (Merdinoglu et al., 2005) and VMC1B11 (Zyprian and Topfer, 2005); the multiplex PCR B included nine markers: VVMD5, VVMD21, VVMD27, VVMD28, VVMD32 (Bowers et al., 1996; 1999), VVIN16, VVIV37, VVIV67 (Merdinoglu et al., 2005) and VMC4F3.1 (Di Gaspero et al., 2000). PCR amplification products were analyzed in an ABI 3130 Genetic Analyzer (Applied Biosystems, Foster City, California, USA), using GeneScan-LIZ 500 as an internal marker (Applied Biosystems), and the fragments were sized with GeneMapper 4.0 software.

\section{AFLP analysis}

All collected samples were further studied using AFLP markers. AFLP reactions were performed according to Vos et al. (1995) with modifications as described by Aguirre et al. (2006). The following primer combinations were used: PE1F (-TGA-3')/PM1H (-GAG-3'), PE1F (-TGA-3')/PM1G (-TCA-3') and PE1I (-AAC-3')/PM1H (-GAG-3'). Electrophoretic separation and staining of PCR products was performed as described for SSR markers.

\section{Statistical analysis}

The results of the microsatellite analyses were recorded as alleles of discrete sizes. To build a dendrogram, a binary matrix was constructed based on the presence/absence of microsatellite alleles. Phylogenetic trees were performed using the Neighbor Joining method with PAUP 4.0b software (Swofford, 1998).

\section{Estimation of genetic diversity}

Genetic diversity was calculated according to Martínez et al. (2006) via observed heterozygosity $[(\mathrm{Ho})=(\mathrm{NHo} /$ NT) 100], defined by the ratio between the number of heterozygous individuals (NHo) and the total number of individuals (NT); the expected heterozygosity $[(\mathrm{He})=$ $\left.1-\sum \mathrm{pi}^{2}\right]$, where $p i$ is the frequency of individual alleles; the effective number of alleles $\left[(\mathrm{ENA})=1 / \Sigma \mathrm{pi}^{2}\right]$; the probability of coincidence $\left[(\mathrm{PI})=\Sigma \mathrm{pi}^{2}\right]$; the cumulative probability of coincidence $\left[\left(\mathrm{PI}_{\mathrm{cum}}\right)=\mathrm{PI}_{1} \times \mathrm{PI}_{2} . . \mathrm{PI}_{\mathrm{m}}\right]$, the product of individual allele frequency; and the frequency of null alleles $[\mathrm{r}=(\mathrm{Ho}-\mathrm{He}) /(1-\mathrm{He})]$.

\section{Filial relationship}

To establish possible filial relationships among accessions, each accession was compared to the rest of the population based on SSR patterns. Two accessions with a match of at least one allele per assayed locus was seen as proof of a possible filial relationship, which was statistically evaluated as described by Milla-Tapia et al. (2007). 


\section{RESULTS AND DISCUSSION}

\section{Genetic characterization of the accessions}

The 21 accessions (Table 1) were characterized using 12 SSR markers, including the set of six SSRs proposed by This et al. (2004), as key sequences to characterize grape germplasm.

Table 2 lists the statistics associated with the 12 SSR markers used. The observed heterozygosity (Ho) varied between 0.5 (VvZAG62) and 1.0 (markers VVS2, VVMD27, VVMD5, VVMD25, and VMC5h5), which is quite uncommon (Santiago et al., 2005). This variability may be due to the low number of genotypes under scrutiny. In contrast, the expected heterozygosity (He) ranged between 0.70 and 0.82 , lower than the Ho in 10 out of the 12 loci studied, and similar to what was observed by Ibáñez et al. (2003) and Martin et al. (2003) for Spanish grape collections. Additionally, the frequency of null alleles ( $r$ ) indicated a positive value for only two markers (VVC9h4-2 and VrZAG72), with low probability, which is in line with what was also observed by Ibáñez et al. (2003).

The total number of alleles per locus ranged from 4 (VVMD7 and VVS2) to 9 (VVMD28). Taking the 12 markers into consideration, these accessions accumulated 72 alleles, with an average of 6.0 alleles per locus (Table 2 ). This value was higher than that previously described by Milla-Tapia et al. (2007), who analyzed a population of 79 accessions with nine SSR markers; but it was lower than that reported by Ibáñez et al. (2003; 2009), who observed average values of 9.85 and 9.96 alleles per locus in a study of 111 accessions with 13 SSR markers and a study of 376 accessions with 25 SSR markers, respectively (Ibáñez et al., 2003; 2009), resulting in the largest genetic diversity index ever reported for any table grape collection.

The probability of identity (PI) ranged between 0.18 and 0.30 for each marker, with this interval being lower than that reported by Ibáñez et al. (2003). This result was not unexpected, given the limited number of genotypes (eight) identified in this collection. On the other hand,

Table 2. Genetic parameters of the $\mathbf{1 2}$ microsatellite markers used in the characterization of the grapevine accessions collected in the Atacama Desert.

\begin{tabular}{lcccccc}
\hline SSR & Nr allele & Ho & He & ENA & PI & R \\
\hline VVMD28 & 9 & 0.88 & 0.78 & 4.5 & 0.22 & 0.050 \\
VVMD27 & 7 & 1.00 & 0.82 & 5.6 & 0.20 & 0.100 \\
VrZAG79 & 7 & 0.88 & 0.83 & 5.8 & 0.17 & 0.030 \\
VrZAG62 & 7 & 0.50 & 0.77 & 4.3 & 0.23 & 0.150 \\
VMC9h4-2 & 7 & 0.75 & 0.80 & 4.9 & 0.20 & 0.030 \\
VVMD5 & 6 & 1.00 & 0.82 & 5.5 & 0.18 & 0.100 \\
VMC5h5 & 6 & 1.00 & 0.82 & 5.5 & 0.18 & 0.100 \\
VVMD25 & 5 & 1.00 & 0.79 & 4.8 & 0.21 & 0.120 \\
VMC8g9 & 5 & 0.88 & 0.70 & 3.4 & 0.30 & 0.100 \\
VMC5g7 & 5 & 0.88 & 0.78 & 4.6 & 0.22 & 0.050 \\
VVS2 & 4 & 1.00 & 0.71 & 3.4 & 0.30 & 0.170 \\
VVMD7 & 4 & 0.88 & 0.71 & 3.5 & 0.28 & 0.090 \\
Total & 72 & - & - & & $1.34 \times 10^{-8}$ & \\
Average & 6.0 & 0.89 & 0.78 & & & \\
\hline
\end{tabular}

SSR: Simple sequence repeat; Ho: observed heterozygosity; He: expected heterozygosity; ENA: effective number of alleles; PI: probability of coincidence. when all of the SSR markers were considered, the cumulative PI $\left(\mathrm{PI}_{\text {cum }}\right)$ was $1.34 \times 10^{-8}$, which indicates that there is a probability of approximately 1 in 90 million for a new entry to genetically match with any of the accessions described here. This probability is higher than that established by Martin et al. (2003), who found a $\mathrm{PI}_{\text {cum }}$ value that was tenfold lower. One possible interpretation of this result is that the germplasm of this collection, though small in number, consists of genotypes of diverse origins and genetic constitution, which is a possibility that must be taken into consideration for the proper management and surveillance of the germplasm.

Based on the genetic data collected, a dendrogram representing the genetic similarity among accessions was constructed (Figure 2). The dendrogram illustrates the complete identity found among ten accessions with red berries that were equivalent to 'País' from Cauquenes (Chile) and 'Hariri' from Morocco. Among the accessions with red berries, six were from the neighboring sites of Codpa and Ofragia, suggesting that the germplasm probably corresponded to the same or similar genetic material. The other four accessions with red berries were from Pica and Suca. All of these accessions exhibited SSR patterns that were identical to that of 'País'.

During the evaluation of the phenotype of these 10 accessions, it was found that accession 22S7, from Suca, exhibited severe millerandage (shot berries). Also, there was another accession, 6S4, which differed from the standard SSR pattern of 'País' in one allele at the VMC5g7 locus. This locus has been described as variable at the intra-cultivar level (Moncada et al., 2006). Considering that somatic mutations at microsatellite loci have a higher probability of occurrence compared to the rest of the nonrepetitive genome, it is possible that accession $6 \mathrm{~S} 4$ is a mutation of 'País'. The subtle difference in allele sizes (2 $\mathrm{bp}$, or one dinucleotide unit) is another piece of evidence supporting this hypothesis, considering the proposed models of evolution of this type of repetitive sequences

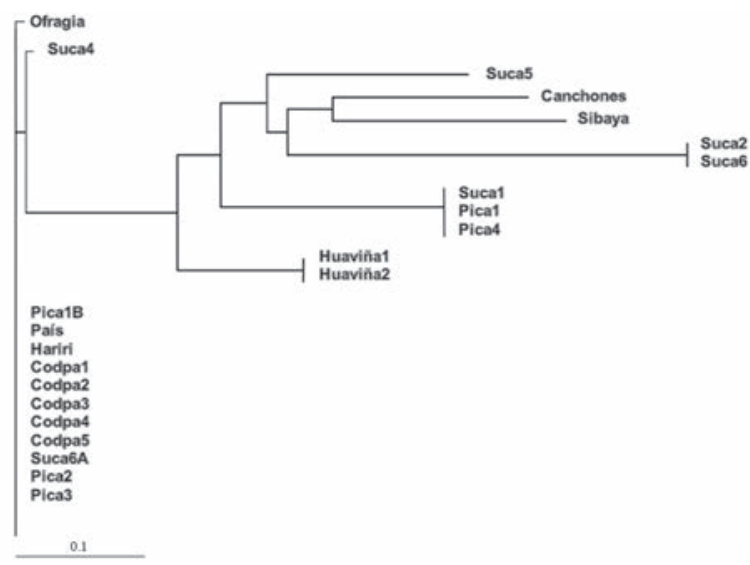

Figure 2. Dendrogram representing the genetic relationships among the grapevine accessions from the Atacama Desert, based on simple sequence repeat (SSR) markers. 
(Xu et al., 2000). This difference could be the result of a mutation occurring during the last several centuries, which is not surprising considering the exposure to high radiation endemic to this region (Lanino, 2008). To evaluate the level of intra-varietal genetic diversity and to search for possible genetic variants, all of the studied samples were genotyped using AFLPs, a marker system used for the characterization of clonal materials (Cervera et al., 1998; Blaich et al., 2007). Three highly informative AFLP markers generated a total of 114 amplicons, which was a similar yield to what was reported by Cervera et al. (1998). However, there was no single consistent and reproducible polymorphism among this set of amplicons. We did observe occasional bands that were rejected as technical artifacts, probably derived from failures in DNA digestion by restriction enzymes, as has been previously described (Benjak et al., 2006). Nevertheless, it was possible to confirm the internal homogeneity of the 'País'-type accessions for this set of markers. At the same time, the differences between this group of accessions and other genotypes bearing white or red colored berries was confirmed (result not shown, available from the authors upon request).

One accession within the group of red berries that differed from the genetic pattern of 'País' was 5CN from La Huayca. This material came from an ancient vineyard located close to Pica (Figure 1). The vines were reportedly introduced and cultivated in the 1950s by German immigrants who produced a wine known regionally as "Canchones" (I. Lanino, personal communication). This genotype was identified, after comparison with the IMIDRA database, as 'Gros Colman' or 'Kharistvala Kolkhuri', which originated in Georgia (Russia) (Tessier et al., 1999).

Contrasting with the results obtained with the red berries accessions, a moderate but larger genetic diversity was found among the white and pink accessions, including five different genotypes, as determined by SSR markers. Among them, the white berry accessions 13P4 and 14P1 from Pica, 18S1 19S2 and 21S6 from Suca, and 16H1 and $17 \mathrm{H} 2$ from Huaviña had the same genetic pattern. There were only two accessions with pink berries: 20S5 and $11 \mathrm{Si}$, both of which displayed different genetic patterns. The nine non-red accessions were classified by the SSR patterns into five groups (Figure 2). Two of them were identified through comparison to our local database and by using the IMIDRA-Madrid database. These accessions were 20S5 (pink), known in Spain as 'Teta de Vaca' and in Algeria as 'Ahmeur bou Ahmeur' (Tessier et al., 1999), and 11Si, which unexpectedly corresponded to the Argentinean variety 'Emperatriz' and is also known as 'Red Seedless' (Ibáñez et al., 2009). It was not possible to determine how this relatively modern accession was established in the Atacama Desert, being most likely the result of anonymous experimental introductions made by local extension programs in recent decades. In addition, accessions $16 \mathrm{H} 1$ and $17 \mathrm{H} 2$, which correspond to the same genotype, could derive from a cross between 'País' and 'Muscat of Alexandria', the parents of a larger set of diverse accessions collected throughout Chile according to Milla-Tapia et al. (2007). The origin of these accessions seems to be recent in America, and an equivalent phenomenon has not been described in Old World grape germplasm. Accessions 14P1, 18S1 and $13 \mathrm{P} 4$, characterized by large white berries with a considerable number of seeds, did not match any genetic pattern of the approximately 1700 accessions managed by the IMIDRA database. It is possible that this genotype corresponds to a chance seedling, as has been proposed in recent studies of other ancient American accessions (Milla-Tapia et al., 2007). Accessions 19S2 and 21S16, also marked by white-seeded berries of small size, did not match any of the known varieties present in Chile or in the IMIDRA germplasm bank.

\section{Possible filial relationship}

Among these accessions, filial relationships are possible among a few of the characterized genotypes. This is the case with the accessions from Huaviña, which shared alleles at 12 markers with 'País' and accession 6S4, with 6S4 being a possible clonal derivative of 'País'. By comparison to the Finca El Encín (Madrid, Spain) database, it was possible to identify 'Muscat of Alexandria' as the accession's other parent. It must be noted that this accession is different from the 12 genotypes identified by Milla-Tapia et al. (2007), which were also considered possible descendants of the cross of 'País' and 'Muscat of Alexandria'. In order to confirm these relationships, a set of 20 additional SSR markers was evaluated on the complete set of accessions, confirming their identity as previously reported and also confirming the proposed filial relationships. The allelic data set from these experiments is available upon request from the corresponding author.

Interestingly, most of the identified genotypes exhibited a low allelic sharing index (Table 3), which indicates that the accessions under study most likely correspond to germplasm introduced from the Iberian Peninsula, as suggested by Billinghurst (1893). It was not possible to elucidate whether the old names cited by Billinghurst (1893), such as 'Italia', 'Mollar de Granada', 'Castellana', 'Bordalesa', 'Moscatel', and 'Tintilla', correspond to some of the accessions described in this

Table 3. Possible filial relationships among different grapevine accessions collected in the Atacama Desert. Numbers indicate the matching of at least one allele per marker. Each genotype is represented by one accession.

\begin{tabular}{lrrrrrrrrr}
\hline & País & $5 \mathrm{CN}$ & $16 \mathrm{H} 1$ & $14 \mathrm{P} 1$ & $19 \mathrm{~S} 2$ & $20 \mathrm{~S} 5$ & $11 \mathrm{Si}$ & $6 \mathrm{~S} 4$ & \\
\hline País & 12 & 7 & 12 & 9 & 2 & 9 & 8 & 12 \\
5CN & & 12 & 7 & 4 & 3 & 8 & 8 & 7 \\
16H1 & & & 12 & 8 & 2 & 9 & 9 & 12 \\
14P1 & & & & 12 & 6 & 9 & 8 & 9 \\
19S2 & & & & & 12 & 7 & 6 & 3 \\
20S5 & & & & & & 12 & 8 & 8 \\
11Si & & & & & & & 12 & 8 \\
6S4 & & & & & & & & 12 \\
\hline
\end{tabular}


work. The only way to address this question would be through the extensive sampling of the Finca El Encín and other international genetic repositories and germplasm collections using these same genetic markers in order to prove or disprove any genetic similarities that were not examined in this study.

\section{CONCLUSIONS}

Of the 21 accessions collected in the Atacama Desert, 10 corresponded to the variety known in Chile as 'País', the same that has been identified throughout America. One genotype with red berries differed from 'País' in one allele. Two other genotypes with red and pink berries were identified as 'Gros Colman' and 'Ahmeur bou Ahmeur' from Georgia and Algeria, respectively. Another genotype with seeded and small white berries corresponded to a cross between 'Muscat of Alexandria' $x$ 'País', a cross that has been previously identified as typical of Americaborn accessions. Two genotypes with white-colored berries were not identified as any known variety.

\section{ACKNOWLEDGEMENTS}

We would like to thank M.H. Castro and G. Ravest for valuable assistance with the laboratory and data analyses, respectively. We also recognize the Centro de Investigaciones del Hombre en el Desierto (CIHDE), Universidad Arturo Prat, the Instituto de Investigaciones Agropecuarias INIA, Chile, and FONDEF Grant D04I1060 for providing partial financial support.

Caracterización genética de vides antiguas colectadas en oasis del desierto de Atacama. Las accesiones de vid (Vitis vinifera L.) de antigua data son una fuente de variantes génicas que pueden ser rescatadas para su uso directo o su incorporación en programas de fitomejoramiento. La primera etapa de este rescate es la colecta y caracterización del germoplasma propio de una región particular. Este estudio describe la caracterización genética de 21 accesiones de vid colectadas en el desierto de Atacama, en el Norte de Chile. La caracterización se basó en 12 marcadores de microsatélites (SSR), complementado con marcadores de tipo fragmentos amplificados de largo variable (AFLP). La mayoría de las accesiones colectadas con bayas negras corresponden al genotipo 'País', un cultivar antiguo que se encuentra distribuido en toda América. Sin embargo, entre las accesiones de baya negra, una de ellas mostró un fenotipo abortivo severo (22S7), y otro (6S4) difirió en un alelo con respecto a 'País'. Ambos podrían ser ejemplos de mutaciones somáticas, aun cuando no fue posible detectar variaciones en sus patrones de AFLP. Por otra parte, la única accesión con bayas negras que exhibió características genéticas diferentes a 'País' correspondió a 'Gros Colman' $(5 \mathrm{CN})$, un genotipo supuestamente proveniente de Georgia, Rusia, introducido en esta región a mediados del siglo XX. Una mayor diversidad genética fue detectada entre las accesiones de bayas blancas y rosadas, que se clasificaron en cinco clados en base a sus alelos de microsatélites. De estos genotipos, $11 \mathrm{Si}$ se identificó como 'Emperatriz' o 'Red Seedless', una variedad de origen argentino, mientras que las accesiones $16 \mathrm{H} 1$ y $17 \mathrm{H} 2$ correspondieron a un cruzamiento de 'Moscatel de Alejandría' x 'País'. Por último, la accesión 20S5 se identificó como 'Ahmeur bou Ahmeur', un genotipo argelino de bayas de color rosado. Dos genotipos semillados de bayas blancas, pequeñas o grandes, no se asimilaron con alguna variedad conocida. Se discute también la posibilidad de utilizar algunas de estas accesiones en fitomejoramiento, para aumentar la tolerancia a estreses propios del ambiente del desierto de Atacama.

Palabras clave: Vitis vinifera, SSR, AFLP, desierto de Atacama, germoplasma, 'Listán Prieto'.

\section{LITERATURA CITED}

Aguirre, C., R. Alvarado, y P. Hinrichsen. 2006. Identificación de variedades y líneas de mejoramiento de arroz de Chile mediante análisis de fragmentos de ADN de largo variable amplificados por PCR (AFLP). Agricultura Técnica 65:356-369.

Benjak, A., J. Konradi, R. Blaich, and A. Forneck. 2006. Different DNA extraction methods can cause different AFLP profiles in grapevine (Vitis vinifera L.) Vitis 45:15-21.

Billinghurst, G. 1893. La irrigación en Tarapacá. 196 p. Imprenta Ercilla, Santiago, Chile.

Blaich, R., J. Konradi, E. Ruhl, and A. Forneck. 2007. Assessing genetic variation among Pinot Noir (Vitis vinifera L.) clones with AFLP markers. American Journal of Enology and Viticulture 58:526-529.

Bowers, J., G. Dangl, and C. Meredith. 1999. Development and characterization of additional microsatellite DNA markers for grape. American Journal of Enology and Viticulture 50:243-246.

Bowers, J., G. Dangl, R. Vignani, and C. Meredith. 1996. Isolation and characterization of new polymorphic simple sequence repeat loci in grape (Vitis vinifera L.) Genome 39:628-633.

Cervera, M.T., J.A. Cabezas, J.C. Sancha, F. Martinez De Toda, and J.M. Martinez-Zapater. 1998. Application of AFLPs to the characterization of grapevine Vitis vinifera L. genetic resources. A case study with accessions from Rioja (Spain). Theoretical and Applied Genetics 97:51-59.

Del Pozo, J. 1998. Historia del vino chileno. 321 p. Editorial Universitaria, Santiago, Chile.

Di Gaspero, G., E. Peterlunger, R. Testolin, K. Edwards, and G. Cipriani. 2000. Conservation of microsatellite loci within the genus Vitis. Theoretical and Applied Genetics 101:301-308.

Ferreyra, R.,A. Aljaro, R. Ruiz, L. Fojas, and J. Oster. 1997. Behavior of 42 species grown in saline soils with high boron concentrations. Agricultural Water Management 34:111-124.

Ibáñez, J., M. de Andrés, A. Molino, and J. Borrego. 2003. Genetic study of key Spanish grapevine varieties using microsatellite analysis. American Journal of Enology and Viticulture 54:21-30.

Ibáñez, J., M. Vargas, M. Palancar, J. Borrego, and M. De Andrés. 2009. Genetic relationships among table-grape varieties. American Journal of Enology and Viticulture 60:35-42.

Lanino, M. 2008. Efecto de tres tasas de riego en el movimiento de sales en cultivo de melón (Cucumis melo) cultivar Galia, en micro canchones y en camellón, en la Pampa del Tamarugal. Tesis de Magíster en Ingeniería Agrícola, mención Recursos Hídricos. 68 p. Universidad de Concepción, Facultad de Ingeniería Agrícola, Chillán, Chile. 
Martin, J., J. Borrego, F. Cabello, and J. Ortiz. 2003. Characterization of Spanish grapevine cultivar diversity using sequence-tagged microsatellite site markers. Genome 46:10-18.

Martínez, P. 1998. La vid y el vino de Tenerife en la primera mitad del siglo XVI. Instituto de Estudios Canarios, La Laguna, Tenerife, España.

Martínez, P., P. Cavagnaro, R. Masuelli, and M. Zúñiga. 2006. SSRbased assessment of genetic diversity in South American Vitis vinifera varieties. Plant Science 170:1036-1044.

Merdinoglu, D., G. Butterlin, L. Bevilacqua, V. Chiquet, A. Adam-Blondon, and S. Decroocq. 2005. Development and characterization of a large set of microsatellite markers in grapevine (Vitis vinifera L.) suitable for multiplex PCR. Molecular Breeding 15:349-366.

Milla-Tapia, A., A. Cabezas, F. Cabello, T. Lacombe, J. MartínezZapater, J., P. Hinrichsen, and M. Cervera. 2007. Determining the Spanish origin of representative ancient American grapevine varieties. American Journal of Enology and Viticulture 58:242251.

Moncada, X., F. Pelsy, D. Merdinoglu, and P. Hinrichsen. 2006. Genetic diversity and geographical dispersal in grapevine clones revealed by microsatellite markers. Genome 49:1459-1472.

Narváez, C., M.H. Castro, J. Valenzuela, y P. Hinrichsen. 2001. Patrones genéticos de los cultivares de vides de vinificación más comúnmente usados en Chile basados en marcadores de microsatélites. Agricultura Técnica 61:249-261.

Santiago, J., S. Boso, J. Martin, J. Ortíz, and C. Martínez. 2005. Characterization and identification of grapevine cultivars (Vitis vinifera $\mathrm{L}$.) from northwestern Spain using microsatellite markers and ampelometric methods. Vitis 44:67-72.
Sefc, K., F. Regner, E. Turetschek, J. Glössi, and H. Steinkellner. 1999. Identification of microsatellite sequences in Vitis riparia and their applicability for genotyping of different Vitis species. Genome 42:367-373.

Swofford, D.L. 1998. PAUP Phylogenetic analysis using parsimony (and other methods). Sinauer Associates, Sunderland, Massachusetts, USA.

Tessier, C., J. David, and P. This. 1999. Optimization of the choice of molecular markers for varietal identification. Theoretical and Applied Genetics 98:171-177.

This, P., A. Jung, P. Bocacci, J. Borrego, R. Botta, L. Constantini, et al. 2004. Development of a standard set of microsatellite reference alleles for identification of grape cultivars. Theoretical and Applied Genetics 109:1448-1458.

Thomas, M., and N. Scott. 1993. Microsatellite repeats in grapevine reveal DNA polymorphisms when analysed as sequence-tagged sites (STSs). Theoretical and Applied Genetics 86:985-990.

Vos, P., R. Hogers, M. Bleeker, M. Reinjans, T. Van De Lee, and M. Hornes. 1995. AFLP: A new technique for DNA fingerprinting. Nucleic Acids Research 23:4407-4414.

Xu, X., M. Peng, Z. Fang, and X. Xu. 2000. The direction of microsatellite mutations is dependent upon allele length. Nature Genetics 24:396-399.

Zyprian, E., and R. Topfer. 2005. Development of microsatellitederived markers for grapevine genotyping and genetic mapping. National Center for Biotechnology Information NCBI, GenBank, Bethesda, Maryland, USA. 